\title{
Made and played in Antarctica: People's music in a far-flung place
}

\author{
Bruce Watson ${ }^{1}$
}

\section{Introduction}

Music plays a key role in social ritual, group bonding and broader social cohesion. It is and has been so in all societies across the world and across history. This is as true in Antarctic communities as it is elsewhere, possibly more so. The way people make and share music as part of their daily lives can provide important insights into their society and characteristics.

This chapter focuses on vernacular or community music made and played at Australia's Antarctic bases. Very little of this music has been published, and nowhere has it been systematically studied. Some is documented in station year books, newsletters and reports, and printed in the ANARE Club's journal, Aurora. A small number of songs have been included incidentally in books. ${ }^{2}$ Some have come to the author through personal communication.

Despite being pervasive in daily life, community music is part of oral culture and transient by nature. It is therefore easily lost and its value easily underestimated.

\section{History}

Music has played an important social role in polar life since the first days of exploration by sea. There is a long maritime tradition recognising the effects of music on morale. Many sea voyages had musicians on board to entertain, and to lead working songs, or shanties. This tradition has been passed down to Antarctic bases.

1 Bruce Watson, 22 Tynan Street, Preston West, VIC 3072, jandbwatson@gmail.com, www.brucewatsonmusic.com.

2 For example, Tim Bowden (1997) The silence calling. Allen \& Unwin, St Leonards NSW; Tim Bowden (1991) Antarctica and back in sixty days. ABC Enterprises, Crows Nest NSW; Archie McLean and Douglas Mawson, eds (2010) The Adelie Blizzard: Mawson's forgotten newspaper 1913. Friends of the State Library of South Australia, Adelaide. 


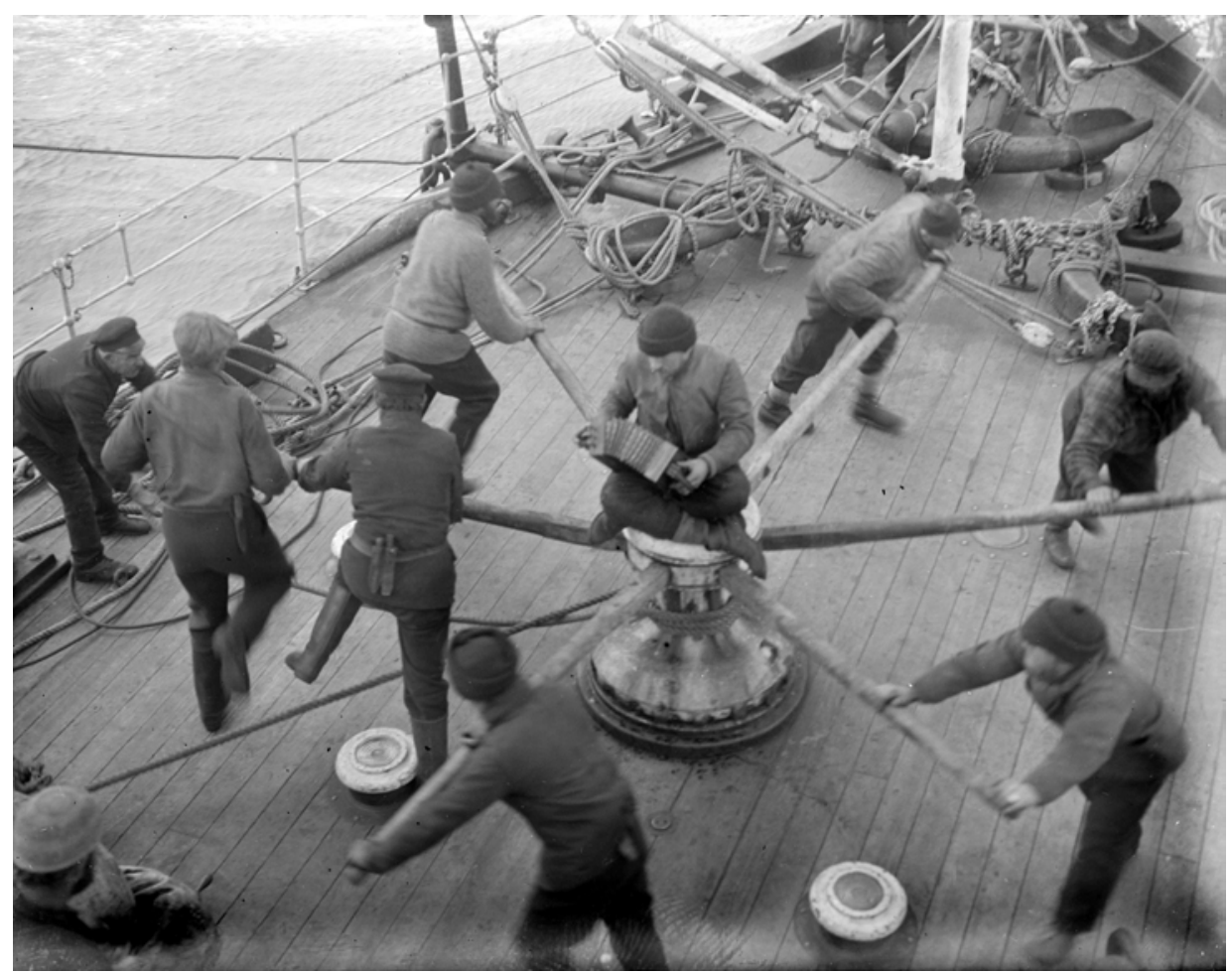

Figure 1. Raising one of the foreyards by use of the capstan on the foredeck. Note chantyman sitting atop the capstan with accordion. He is providing the rhythm for the team of sailors to work to.

Source: Photograph by Frank Hurley. Australian Antarctic Division, (C) Commonwealth of Australia.

Francis Drake took four musicians including a trumpeter on the Golden Hind. ${ }^{3}$ William Bligh took a blind fiddler on the Bounty for morale. ${ }^{4}$ (It didn't work!) Being blind, he would have had no crewing function other than as a musician.

When Ernest Shackleton abandoned the ice-bound Endurance in 1915, he allowed everyone only two pounds of bare essentials. The one exception was Leonard Hussey's banjo. When Hussey queried whether they should take it, Shackleton said, 'It's vital mental medicine and we shall need it.' ${ }^{5}$ And he was right. Twenty-two of Shackleton's men lived on Elephant Island in the South Atlantic for four months under an upturned boat waiting to be rescued. Frank Hurley said, 'Living in the hut we had very little to do. We used to make up songs about one another and sing them at our Saturday night concerts, where

3 Ian Woodfield (1995) English musicians in the age of exploration. Pendragon Press, Stuyvesant, NY, p. xiii; John Cummins (1997) Francis Drake: lives of a hero. St Martins Press, New York, pp. 49, 73.

4 Woodfield (1995) English musicians in the age of exploration, p. 86.

5 LDA Hussey (1949) South with Shackleton. Sampson Low, London, p. 65. 
our only musical accompaniment was the banjo. Of course our songs were very uncomplimentary, but if someone objected, we made up a worse one about him the next week. And that way we kept ourselves alive and more or less amused.' ${ }^{6}$

Here is part of one of those songs, to the tune of the music hall ditty 'Solomon Levi':

My name is Frankie Wild-o! and my hut's on Elephant Isle;

The wall's without a single brick, and the roof's without a tile;

Yet nevertheless you must confess, in many and many a mile,

It's the most palatial dwelling-place you'll find on Elephant Isle. ${ }^{7}$

From the first presence of Australians on the Antarctic continent, 'sledgometer verse' was made up by explorers to sing or recite to themselves and others during the long blank hours of the daily march. ${ }^{8}$ Elizabeth Leane describes this verse as motivational in both form and content. Frank Hurley's 'Southern Sledging Song' is an example, sung to the simple tune of 'Sailing, Sailing':

Hauling, toiling, tireless on we tramp

$\mathrm{O}^{\prime}$ er vast plateau, sastrugi high, o'er deep crevasse and ramp

Hauling, toiling through drift and blizzard gale

It has to be done, so we make of it fun,

We men of the Southern Trail! ${ }^{9}$

This is one of many songs included in The Adelie Blizzard, the monthly paper of those wintering with Mawson in 1913 at Commonwealth Bay. The songs capture the hardships and pleasures of daily life in that place and time.

'A Song on one of the Rare Occasions on which it was Possible to Smoke Outside'

(Tune: 'Eton Boating Song')

Jolly smoking weather

And a Boat-Harbour Breeze

Walking in boots of leather

Standing upright with ease

And we'll smoke, smoke together

Striking matches whenever we please

And we'll smoke, smoke together

\footnotetext{
6 Vital Mental Medicine: Shackleton's Banjo. BBC Radio 4, broadcast 11 December 2010. www.bbc.co.uk/ programmes/b00wdgr5, accessed 8 March 2011

7 Hussey South with Shackleton, p. 141.

8 Elizabeth Leane (2012) Antarctica in fiction: imaginative narratives of the Far South. Cambridge University Press, Cambridge, p. 124

9 McLean and Mawson The Adelie Blizzard. This song was included in vol. 1 no. 1, April 1913.
} 
Striking matches whenever we please...

Soon we'll be back in Australia

Where pipes don't have to be thawed

And watches outside never fail ya

Come into the garden, Maud!

But we'll never forget, inter alia

Those few calms allowed by the Lord

No we'll never forget, inter alia

Those few calms allowed by the Lord. ${ }^{10}$

Most diaries and accounts from the early days of exploration include many references to the expeditioners singing together or listening together to the gramophone.

Musical instruments were taken to Antarctica from the earliest days. Phillip Law, who oversaw the establishment of Australia's permanent presence in Antarctica, was an accomplished musician and took his accordion with him on voyages. He clearly enjoyed a good tune, and would play on many important occasions. In 1955, to celebrate the landing and establishment of Mawson base, the first on the Antarctic mainland, 'Law made hot, spiced glühwein for the occasion and played his piano accordion during the festivities'. ${ }^{11}$

Law recognised the bonding and the boost for morale that a singalong can provide. In the 1950s he even put together the ANARE song book. ${ }^{12}$ There are many photos of him leading singalongs, some with the book. It was used for many decades. As recently as 2010 the station leader at Davis wrote:

The afternoon's feasting ... was consumed to the sounds of the ANARE songbook in digital form courtesy of SL (me). Funny but I haven't had many orders for the CD. My favourite number is No. 140: 'Always true to you darlin' in my fashion. ${ }^{\prime 3}$

10 McLean and Mawson The Adelie Blizzard vol. 1 no. 5, October 1913.

11 Bowden (1997) The silence calling, p. 122.

12 ANARE song book (anonymous and undated) [Presumed publisher ANARE Club], Melbourne.

13 www.antarctica.gov.au/living-and-working/stations/davis/this-week-at-davis/2010/this-week-at-davis25-june-2010, accessed 23 February 2012. 


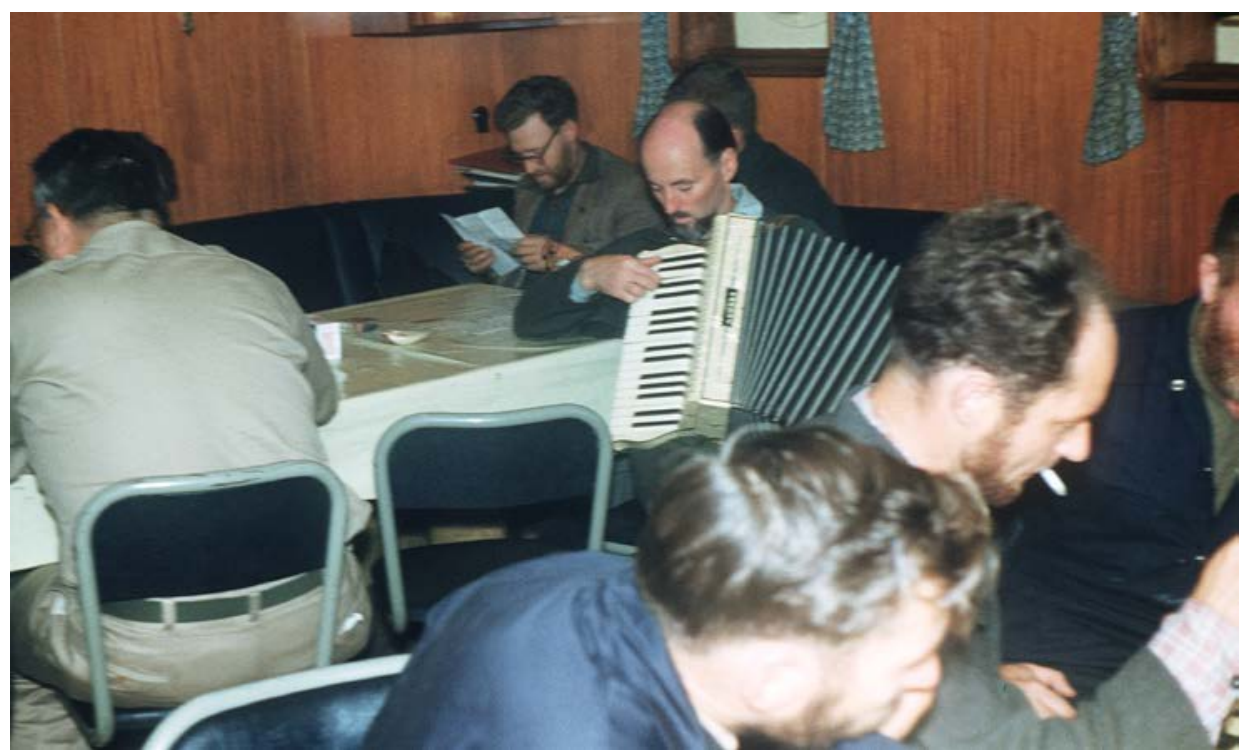

Figure 2. Phil Law playing his accordion, on ship.

Source: Photograph by Peter King. Australian Antarctic Division, (c) Commonwealth of Australia.

\section{Music and community in the Antarctic}

In some respects Australia's Antarctic bases are like any other community; each member brings all their personal and cultural background with them. However, they are in a very different, unique place: in a small, temporary closed society in a stunning but physically difficult environment - similar to shipboard communities.

Both these similarities and differences from mainstream society are reflected in music in Antarctica, as communities swell and contract each year. Communities are constantly changing and renewed from back home. There is some continuity of culture, and traditions develop, but there is far more rapid change than in most communities.

There is a degree of randomness in the nature of Antarctic community music at any given base in any given year, depending on who is there. It may be country, jazz, folk, pop, rock, reggae, funk, blues, singer-songwriter, and sometimes classical. Mostly it is music that people can participate in, in some way: playing (skilfully or not), tapping out percussion, singing along, or dancing. Some years a station has a 'house band'. Sometimes these bands morph from summer to winter to summer to winter, with evolving membership and repertoire. 
But rituals and musical forms are passed down and have grown over the years, such as Midwinter festivities and theme-party nights. ${ }^{14}$ These are a catalyst for making up and performing many songs.

\section{The songs}

Community music tends to be simple, catchy and repetitive. This makes it easy to share, and sharing is part of its power, as a mode of group bonding and a catalyst for it.

Cover songs are performed and are popular, as people know them and can sing along. My research focuses on the music that people have written in Antarctica. There would be hundreds of such pieces. While some have been documented, many exist only on scraps of paper tucked away in people's bottom drawers, or in the heads of those who made them up or sang along.

This paper draws on around 60 collected so far. While it is too small a corpus to enable a statistical analysis, some patterns begin to emerge:

1. Most are humorous songs, many written for special occasions. A small number are lyrical descriptions of Antarctic life. Personal songs are rare. These characteristics contrast with Antarctic poetry, where the pattern is reversed. While humorous poems do exist, Antarctic poetry is primarily lyrical and much more introspective. Community music tends to be about fun and building social cohesion through humour rather than about artistic expression.

2. Most are written to well known tunes: popular songs, folk songs, songs from musicals. This reflects the democratic nature of this music - it is not for specialist composers. Anyone can put a new set of words to an existing song, and it is often done very cleverly.

3. Of the humorous songs, almost all are about the shared experiences of Antarctic life: the weather, the living conditions, the jobs, the food, drinking, travel, equipment, animals, specific incidents - and the people.

The remainder of this section discusses some examples of these themes.

The first is about a series of incidents. It refers to weasels; amphibious snow vehicles used from the 1940s to the 1990s. Bob Dovers had a few mishaps with

14 Bowden (1991) Antarctica and back in sixty days, pp. $112 \mathrm{ff}$ and passim; Bowden (1997) The silence calling, pp. 219-20, 228, 446 and passim. 
them, breaking through the sea ice, requiring chain block winches to retrieve them. Even reading the words on the page, in one's mind's ear one can hear everybody singing along and having a light-hearted go at Dovers!

'Chain Blocks'

(Bill Harvey, Mawson 1954. Tune: 'My Bonnie')

Bob Dovers has ditched his new weasel

Bob Dovers has done it again

Three times it has been in the ocean

It's odds on he'll be there again

Chain blocks, chain blocks

Oh bring back my weasel to me, to me

Chain blocks, chain blocks

Oh bring back my weasel to me.$^{15}$

This next example is also about a key part of Antarctic life.

'Mawson Tractor Song'

('Frosty' McDonald, Mawson 1962. Tune: 'The Deadwood Stage')

The tractor train is rollin' over the plains

The driver's cold but he never never complains

Beautiful sky, a wonderful day

So drift stay away, drift stay away, drift stay away

The tractor train is comin' over the crest

Like a homin' pigeon a hankerin' for its nest

Twenty-three miles to cover today

So drift stay away, drift stay away, drift stay away ${ }^{16}$

A third example of a song describing Antarctic life is this one to the tune of 'Click Go the Shears', a popular tune to parody. This song comes from 1966, the year this tune was used for the jingle to explain decimal currency. Some of its sentiments are very dated, reflecting the culture of its time.

'Antarctic Theme Song'

(Betty Thiele for Stan Taylor, Wilkes 1966. Tune: 'Click Go the Shears')

Down in the Antarctic, no cares to bother us

No dodging Sunday drivers, all in a bloody rush

No sheilas or taxes - no decimal currency

It's a man's world down under, though it lacks luxury

15 Tim Bowden (1997) The silence calling, p. 117.

16 Pers. comm. from John 'Snow' Williams. 
Chorus:

Down in the Antarctic, with the penguins and the snow

Where there are no Bondi beaches, and the flamin' blizzards blow

We're intellectual characters, so when we're feeling blue

We sing and drown our sorrows in a good old fashioned brew ... ${ }^{17}$

While most songs describe or recount stories about Antarctic life, many are about the people - sometimes individuals, but mostly a catalogue of the cast of characters at the base and something memorable about every one of them, often embarrassing. Again, there is a strong social and morale function: sharing stories of life and people, just like Shackleton's crew on Elephant Island.

Friendly insulting in song can strengthen social bonding by breaking down barriers of formality and role. It asserts that you belong, and those you are targeting belong, because you can do this without giving offence.

You will often read in accounts of performances that there is a bit of humorous insulting traded back from the audience. Even Mawson writes that the audience for the semi-impromptu performance of the opera The Washerwoman's Secret was 'crowded on a form behind the dining-table, making tactless remarks' ${ }^{18}$

Much of the music at Midwinter celebrations parallels the parody structure of the Cinderella play which is often performed as part of Midwinter. A standard story or song is adapted to local circumstances, gently breaking rules and conventions of decency, hierarchy, customs. Colleagues are insulted and sexual innuendo and scatological humour are key ingredients!

Following are sample verses from two songs about the year's cast of characters. Variations of the first song below have been sung at different bases over many years. These songs are very long, with one or more verses per person.

\section{'REPSTAT Song' 1966 version}

(Rod MacKenzie, Wilkes 1966. Tune: 'Botany Bay')

Geoff Smith you know is our leader

A job that he does just fine

He taught us to put up the buildings

And also to sing Clementine

Frank Smith is our deputy leader

So you can see that we're well led

17 Aurora [journal of the ANARE Club], March 1967, p. 33.

18 Douglas Mawson (1915) The home of the blizzard, EBook \#6137, ch. 11 www.gutenberg.org/ files/6137/6137-h/6137-h.htm, accessed 23 February 2012. 
He's a beauty at cleaning up chunder

And putting sick people to bed ... ${ }^{19}$

'My Favourite People'

(Anon., Casey 1992, Tune: 'My Favourite Things')

Dev in a turban, chapattis and bourbon

Foods which are spicy and all things suburban

Foods with a kick, things with wheels that go quick

These are a few of his favourite things...

Pat our Pom plumber has hangovers in Summer

Works in the crap farm, the smells are a bummer

What he can do with a plunger or two

What goes in your loo he can tell you that too... ${ }^{20}$

Many songs are written for other special occasions, such as birthdays or Christmas.

'The Twelve Days of Christmas'

(Anon., Davis Christmas 2005)

On the 12th day at Davis the Station Leader gave to me...

Twelve-minute showers ...

Eleven dodgy forecasts,

Ten tonnes of sewerage,

Nine angry tradies,

Eight all-Davis emails,

Seven types of pastas,

Six Chinese lagers,

A spaaare CASA Skiii...

Four weeks of slushy,

3-minute showers,

Two Saturday duties,

And a chopper ride to the A-mer-y. ${ }^{21}$

19 Ian Mackie (1982) ‘REPSTAT summer party 1965-66’. Aurora 2(5) Sept: 13-14. 'REPSTAT’ (rep[lacement] + stat[ion]) was the name given to the Wilkes station following its handover to Australia from the United States. It was later renamed Casey.

20 Casey station yearbook 1992, held by the Australian Antarctic Division Library, Kingston.

21 www.antarctica.gov.au/living-and-working/stations/davis/this-week-at-davis/2006/january-2006/6january-2006, accessed 23 February 2012. 


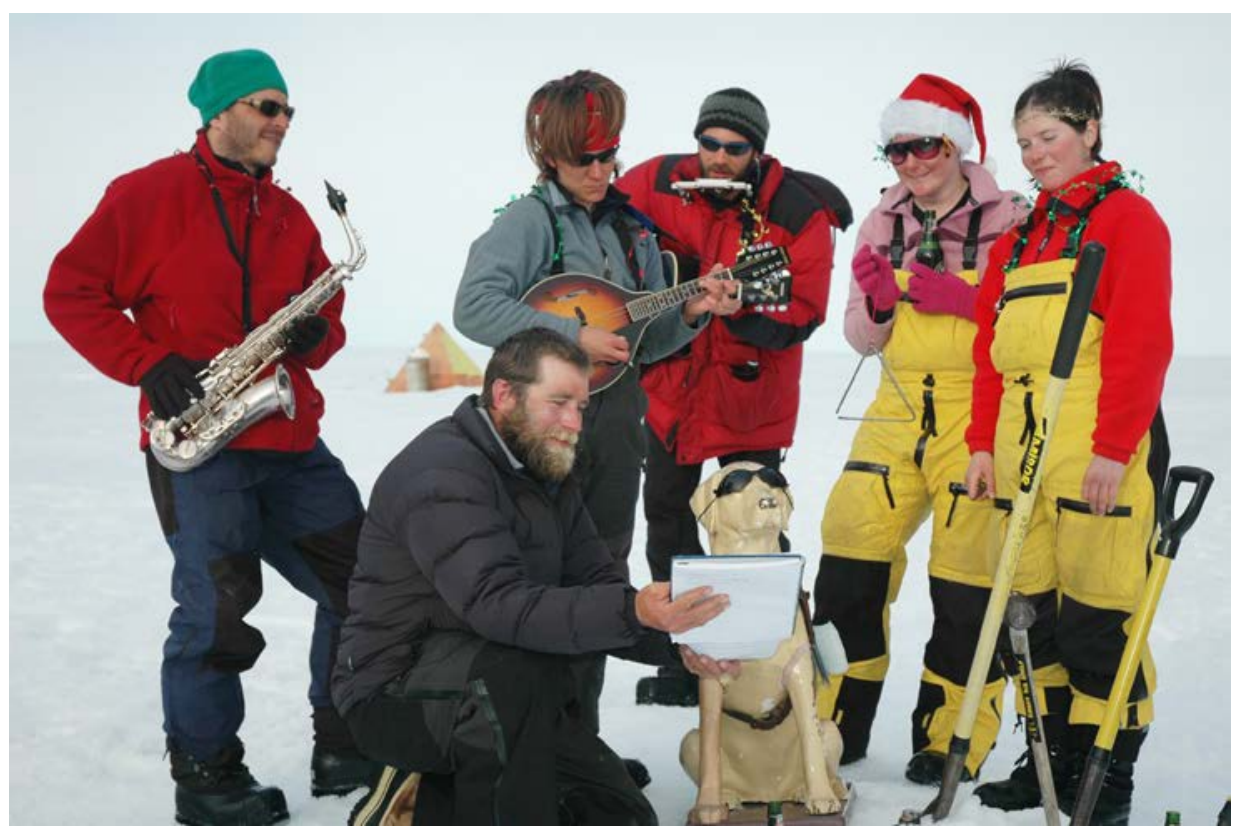

Figure 3. Christmas carols on the Amery Ice Shelf, 2006.

Source: Photograph by Shavawn Donoghue. Australian Antarctic Division, (C) Commonwealth of Australia.

Out of context these songs may appear trite, but on the Antarctic bases they always receive a rapturous reception - without fail. There is no doubt that they fulfil that function of community bonding.

From the heroic era to the present day, the musical style may change with fashion, but there are no real differences in these characteristics of humour, parody, and the gentle insults. This suggests that they continue to fulfil an ongoing social function.

Some suggest that more recent songs are less bawdy with introduction of women and a code of conduct — but that is not necessarily the case.

One change in fashion is a trend away from traditional/folk songs and towards pop songs, mostly Australian, reflecting the same trend in Australia as a whole, as well as the strong Australian pop scene in recent decades. Here is an example. 
'To the Floor'22

(John Innes, Davis 1999. Tune: 'To Her Door', Paul Kelly)

They got in a Hagglunds

She had to get a licence

Tomsy gave a lesson

It went a bit like this

They started up and checked it,

Then she started driving

She drove it pretty slowly

- It really was the pits

John said, 'I'm not standing by

To watch you slowly drive

Press that pedal, to the floor,

To the floor, to the floor, to the floor' ...

\section{The instruments}

From the start, the piano was an essential item at every base. But it was not always used. The 1948 Heard Island party had a piano in their little rec room. It took half a day's work to get it there from the boat. Only then did someone ask, 'Who can play?' — Dead silence! ${ }^{23}$

People have always taken their own instruments to play or to learn during the long, isolated winter: guitars, mouth organs, accordions, saxophones, trumpets, clarinets, flutes, violins, trombones, banjos, ukuleles - and more bagpipes than may be considered good taste.

There are many examples of people making their own instruments; some as basic as improvised percussion on kitchen utensils, and some very elaborate projects. The tea chest bass was common, as was the lagerphone (bottle tops nailed to a long stick which is hit with a short stick).

Some of the homemade instruments have required great ingenuity, becoming exercises in collaboration across the community. An entry from the station log at Mawson in 1960 says: 'George again spent nearly all Friday night making a bass fiddle. It looks like the genuine article, sounds good and damn me he plays it well.' Bill Singleton made a bugle at Mawson in 1984. On Macquarie Island in 1959 George Casasayas made a three-string violin from an old jam tin. The bow was made using cotton thread. The carpenter made resin for the bow by heating

22 Davis station yearbook 1992, held by the Australian Antarctic Division Library, Kingston.

23 Bowden (1996) The silence calling, p. 55. 
wood from an old packing box. On Macquarie Island in 1965 John Jenkin made a drum from an old custard tin and rabbit fur. They used an encyclopedia to work out how to tan the hide and the carpenter helped with wood to stretch the skin.

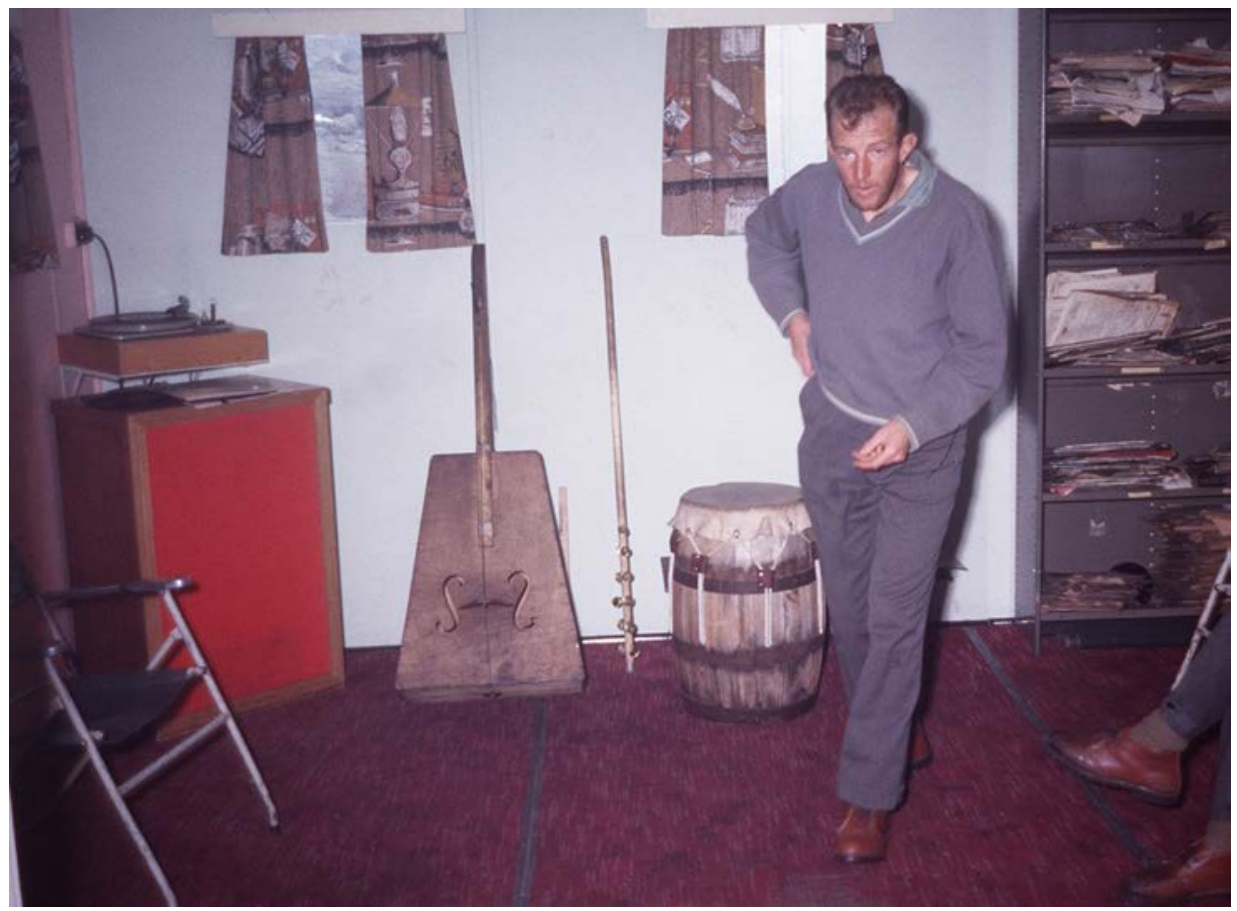

Figure 4. Music room, Mawson.

Source: Photograph by Donald Styles. Australian Antarctic Division, C Commonwealth of Australia.

\section{Music and social cohesion}

Station yearbooks and reports provide recognition of how important community music is.

The 1979 Mawson station leader's report, in assessing morale that year, says: 'A limiting factor on the social scene was our lack of any really competent musicians. I realise this is the luck of the draw, but can well imagine the advantages in having a so gifted expeditioner.'24

24 Mawson station leader's report 1979, held at the Australian Antarctic Division Library, Kingston. 
Keith Lodwick, describing life on Heard Island in 1954, says: 'The piano was a great asset to the camp amenities; it was always a nice relaxation for Jack Walsh who played anything from bawdy songs to Beethoven. ${ }^{25}$ So all that effort getting the piano there in 1948 eventually paid off!

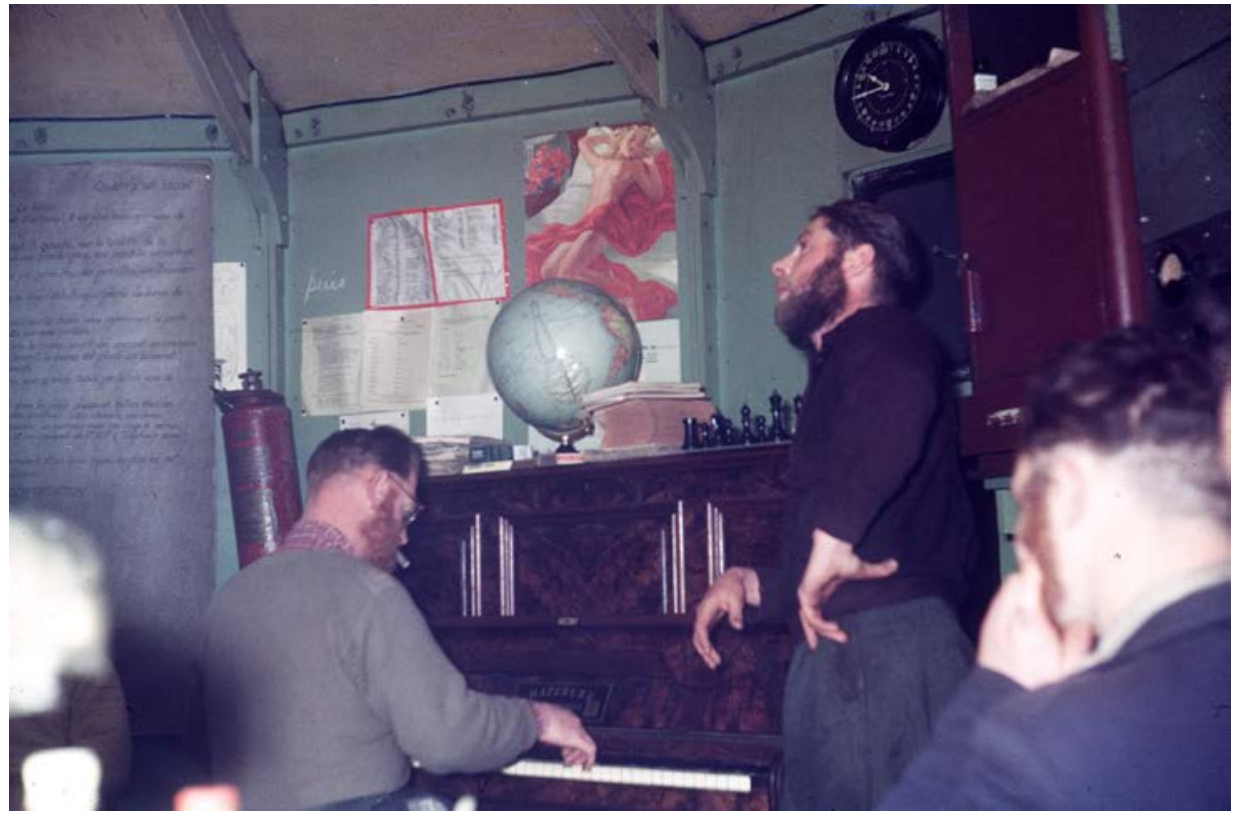

Figure 5. A 'ding' [party], Atlas Cove, Heard Island, 1953-54.

Source: Photograph by Fred Elliott. Australian Antarctic Division, (C) Commonwealth of Australia.

The 2005 Davis yearbook says, 'Music played a central role in keeping people happy and sane throughout the year, whether you're one to make noise or just listen ... There's something addictive about getting together with a group of people and making music. ${ }^{26}$

House bands bond and develop their skills over the winter and tend to peak in the second half of the year - just as morale often dips after Midwinter. Music provides a valuable means to counteract the annual mood cycle.

\section{Change and continuity}

Reflecting broader social change, there is less homemade music making now in Antarctica - just as there is in Australia. There are so many newer forms of

25 Keith Lodwick (2006) 'Notes on expedition to the Antarctic 1954-1955'. Aurora 5(5), Sept: 18-20.

26 Davis station yearbook 2005, held by the Australian Antarctic Division Library, Kingston. 
entertainment to compete for people's attention now. In Antarctica the internet enables people to spend more time in touch with home, and for their emotional lives to be lived more at home, and less totally on the Antarctic base. There is less social bonding, and probably less need for it. The social role of music appears to be decreasing as a result.

Better station facilities have also fragmented the space in which leisure time is spent. It is no longer all in the rec room, with a negotiated timetable of shared activities, including music-making and singing. There are separate spaces for different activities and less time spent all together. The 'slushy' may still choose the music to be broadcast across the station, but it is easier for others to put on the headphones and listen to their own playlist on their iPod.

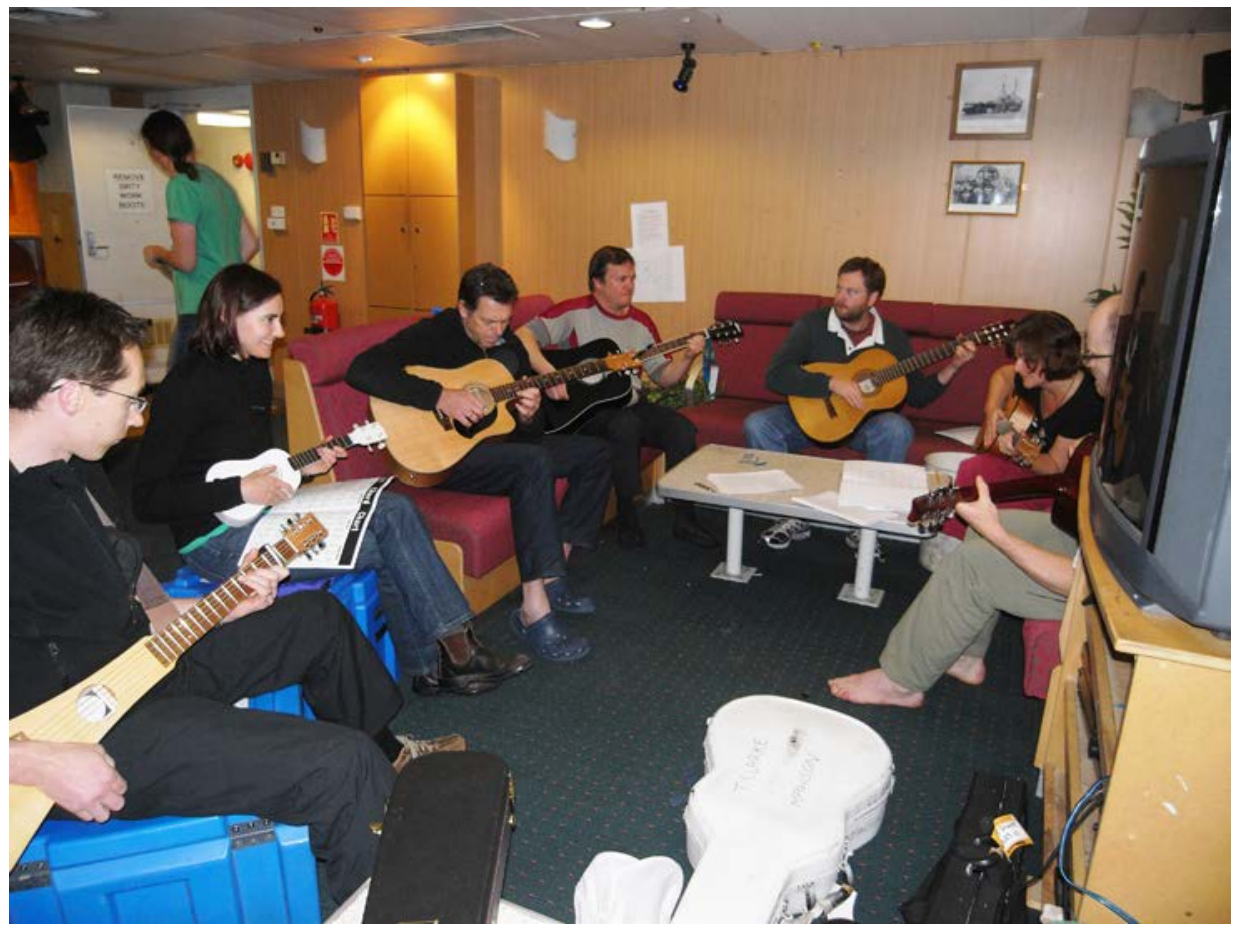

Figure 6. Singalong on ship.

Source: Photograph by Eric Philips. Courtesy Australian Antarctic Division, (C) Commonwealth of Australia.

For all that, there is still the occasional singalong - it is just less common. It is the same in Australia. It cannot be measured objectively, but anecdotal evidence suggests that it is more common in Antarctica than Australia because, despite the changes, there is still very strong community. Unlike most communities, Antarctic communities have a small number of people in an isolated place with a common purpose. And while public space may be more fragmented than it 
once was, it is nowhere near to the same extent as in suburbia or an apartment block. There is still more social need and more opportunity for making music together in Antarctica.

There are also influences that encourage community music making. These include the rise of karaoke, which is a more modern way in which way ordinary people have fun together with music, even if it doesn't involve original songs. In addition, facilities for music at Australia's Antarctic bases have developed from the piano in the rec room to organised, dedicated music rooms with keyboards, drum kits and electric guitars. This encourages the formation of bands and makes it easier to practise.

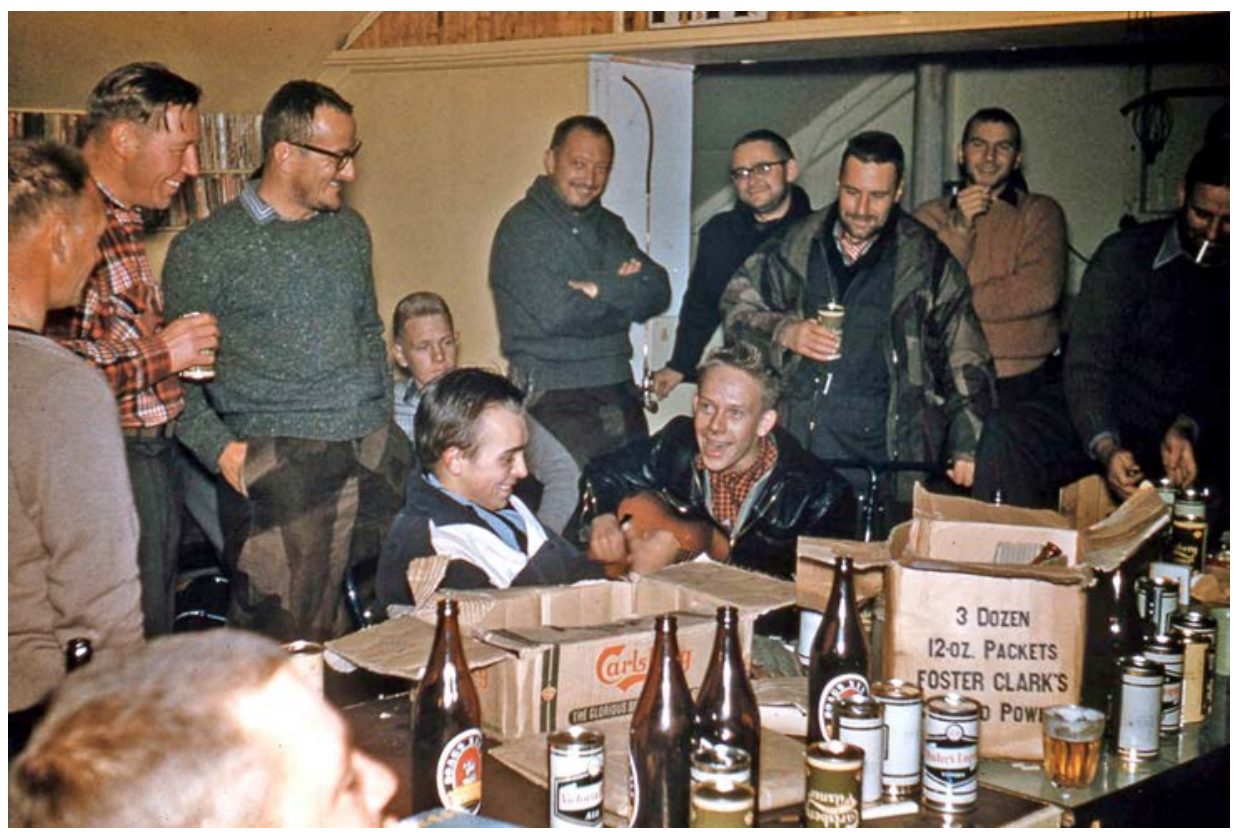

Figure 7. 'Changeover \& new faces. And more beer! And a guitar player with new songs. Always a high point of the year', Mawson station.

Source: Photograph by Grahame M Budd. Australian Antarctic Division, (c) Commonwealth of Australia.

\section{Conclusion}

Community music plays a key role in Antarctic life and in building community: bringing joy, sharing and re-telling experiences. It continues to change, reflecting changes to infrastructure and broader cultural and technological progress in Antarctica and the world. Yet it retains its own special characteristics, reflecting the uniqueness of the place and its community life. 
It is striking how these songs unconsciously, yet uncannily, distil so many facets and details of ordinary life and culture that do not otherwise get documented. The examples in this paper may lack subtlety, but if you examine the verses closely you see rich detail delivered with economy. It is all a bit of fun, but what we do for fun can tell us a lot about ourselves and our society. 
This text is taken from Antarctica: Music, sounds and cultural connections, edited by Bernadette Hince, Rupert Summerson and Arnan Wiesel, published 2015 by ANU Press, The Australian National University, Canberra, Australia. 